Marquette University

e-Publications@Marquette

College of Education Faculty Research and

Publications

Education, College of

Spring 2020

\title{
The Role of Social Justice Living-Learning Communities in Promoting Students Understanding of Social Justice and LLC Involvement
}

Jody Jessup-Anger

Marquette University, jody.jessup-anger@marquette.edu

Megan Armstrong

University of Wisconsin - Madison

Brianne N. Johnson

Marquette University, brianne.johnso@marquette.edu

Follow this and additional works at: https://epublications.marquette.edu/edu_fac

Part of the Education Commons

\section{Recommended Citation}

Jessup-Anger, Jody; Armstrong, Megan; and Johnson, Brianne N., "The Role of Social Justice LivingLearning Communities in Promoting Students Understanding of Social Justice and LLC Involvement" (2020). College of Education Faculty Research and Publications. 541.

https://epublications.marquette.edu/edu_fac/541 
The Review of Higher Education

Spring 2020, Volume 43, No. 3, pp. 837-860

Copyright (C) 2020 Association for the Study of Higher Education

All Rights Reserved (ISSN 0162-5748)

\title{
The Role of Social Justice Living-Learning Communities in Promoting Students Understanding of Social Justice and LLC Involvement
}

Jody E. Jessup-Anger, Megan Armstrong, and Brianne Johnson

\begin{abstract}
In this qualitative, multiple-case study, we explored 30 students' experiences across three social justice living-learning communities (LLC) to understand their conception of social justice and LLC involvement. Moreover, we examined the community elements that advanced these outcomes. Despite
\end{abstract}

Jody E. Jessup-Anger is associate professor of higher education and program coordinator of the Student Affairs in Higher Education master's program at Marquette University. Her research explores how the interaction of students and the collegiate environment affects student development and learning.

Megan Armstrong is an academic advisor at the University of Wisconsin-Madison. She is a graduate of Marquette University's Student Affairs in Higher Education master's program.

Brianne Johnson is a student affairs educator with a passion for social justice who recently relocated to Milwaukee, Wisconsin. Prior, she was assistant director for university-community partnerships at the University of Michigan's Ginsberg Center for Community Service and Learning. She is a graduate of Marquette University's Student Affairs in Higher Education master's program.

Correspondence about this manuscript should be addressed to: Jody Jessup-Anger, Department of Educational Policy and Leadership, Marquette University, PO Box 1881, Milwaukee, WI 53201. Email: jody.jessup-anger@marquette.edu 
similar goals across communities, students demonstrated variation in their understanding of and commitment to involvement in social justice initiatives. We advance a typology describing patterns of involvement and social justice understanding in which we categorize students into four quadrants, including informed activist, informed bystander, uninformed volunteer, and uninformed bystander. Further, we describe contextual elements that influenced these patterns, discussing implications for practice.

\section{INTRODUCTION}

Over the past half century, learning communities evolved from being viewed as an innovation adopted in isolation by postsecondary institutions to a wide-spread reform movement embraced by over 800 colleges and universities (Matthews, Smith, \& MacGregor, 2012). Institutional support for these communities deepened when they were identified by the American Association of Colleges and Universities (AAC\&U) as a 'High Impact Practice' (AAC\&U, 2007), which indicated that students who participated in them reported greater gains in learning and personal development. Other researchers echo these claims (see Taylor, Moore, MacGregor, \& Lindblad, 2003 for a comprehensive review).

Given the powerful potential of learning communities in promoting student growth and development, these communities are well-situated to engage students in conversation about vexing societal problems. One such problem, articulated by the National Task Force on Civic Learning and Democratic Engagement (2012) in A Crucible Moment: College Learning and Democracy's Future, is the "anemic civic health" (p. 1) of today's graduates, who report few opportunities in postsecondary institutions to develop greater understanding of U.S. or global social, political, and economic issues. Although postsecondary institutions encourage students' civic participation in numerous ways, with many requiring civic, diversity, and social justice education as part of general education requirements (Spiezio, Baker, \& Boland, 2006), a more integrative approach may be warranted to advance students' knowledge, skills, capacity, and action toward social justice understanding.

Throughout this paper, the term civic engagement is used to convey one's sense of responsibility to the broader community and actions that are consistent with that belief (Rowan-Kenyon, Soldner, \& Inkelas, 2007). Social justice is often linked with civic engagement and is defined as work toward ending the system of oppression that gives certain social groups greater privilege and power over others (Broido, 2000). The terms civic engagement and social justice are often coupled because of their awareness and action orientations; citizens must be aware of and feel responsible for social inequity before they are inspired to work for social change at the individual, cultural, and institutional levels (Boyle-Baise \& Langford, 2004; Einfeld \& Collins, 2008). 
Many social justice learning communities seek to provide avenues for students interested in social justice and civic engagement to connect with others, get involved in their communities, and deepen their understanding of social justice. These types of learning communities are structured differently; students may live together, take part in a shared course, do community service and other civic engagement activities together, or some combination thereof. The purpose of our study was to examine students' experiences in three social justice-themed living-learning communities (LLCs) to explore whether and how these communities promoted students' understanding of social justice and LLC involvement. We sought to understand the importance of different elements of these communities (classes, peer interactions, community service) in deepening both students' understanding of social justice and their LLC involvement.

\section{EMPIRICAL LiTERATURE}

We drew upon LLC and social justice education research to inform the design of our study. Most closely related to our study, Rowan-Kenyon, Soldner, and Inkelas (2007) used quantitative data from the 2004 National Study of Living Learning Programs to examine the contributions of LLCs on developing students' sense of civic engagement. Not surprisingly, the researchers found that students living in civic participation-focused LLCs exhibited a stronger sense of civic engagement than peers in other LLCs and traditional residence halls. However, once pre-dispositional attitudes toward civic engagement were added to the model the LLC effect was not significant. The authors surmised that because the students were already interested in civic engagement, the LLC alone was insufficient to advancing that engagement. Women were more civically engaged than their male counterparts. Because of the unclear role of the LLC in promoting civic engagement, more research is needed to understand how these communities might promote such understanding and engagement.

Research conducted by Wawrzynski and Jessup-Anger (2010) illustrated the potential of resource allocation to affect learning-community outcomes. Their quantitative study found that students who lived in comprehensively resourced communities, with classes or sections of classes reserved for those students and strong integration of faculty and student affairs support, reported more enriching academic experiences and greater academic interactions with peers. However, no learning-community specific outcomes (like social justice understanding or LLC involvement) were measured. In a related qualitative study, Wawrzynski and colleagues (2009) looked at students' experiences in comprehensively resourced communities and found that these communities created a learning-focused culture that promoted connectedness among students, faculty, and staff. 
More specific to social justice learning communities, Watterson, Rademacher, and Mace (2012) outlined the development of a curriculum situated in a social justice-themed learning community, shedding light on how a learning-focused culture might be developed. The authors, who also taught in the living-learning community, articulated how they integrated their courses across the LLC with the goal of providing students with coherence, mutual construction of knowledge, and engagement in pluralism. Despite their careful design of the community, they did not report outcomes of any assessment. Thus, more research is necessary to determine how students' participation in these communities advances their understanding of social justice, deepens their action toward social justice, and which specific elements of the communities do so.

As we embarked on research related to these communities, we explored the following questions:

1. How does living in a social justice-themed LLC shape students' understanding of social justice and LLC involvement, if at all?

2. What elements (if any) of their social justice-themed LLCs did students identify as helping to deepen their social justice understanding and involvement in the LLC?

\section{Methodology}

\section{Researcher Positionality}

Our positionality as researchers is worth noting. Each author had prior experience working in residence life, and the first and third authors had experiences working within LLCs, though none worked within residence life or LLCs at the time the study was conducted. Based on our experiences, we had seen varying levels of student involvement in and institutional commitments to these communities. All three authors held an interest in understanding the potential role of the university as a tool for social justice. These experiences guided the types of questions we asked and helped us to build rapport with participants. The perspectives also shaped our analysis, as we were attentive to potential variation in students' commitment and the organizational structures supporting these communities.

\section{Theoretical Framework}

We used a multiple, qualitative case study approach (Yin, 1984) to explore students' experiences in these social justice-themed LLCs, focusing on students' understanding of social justice and LLC involvement. A constructivist epistemology (Broido \& Manning, 2002) guided the study design. The constructivist perspective (Piaget, 1972) aligned with our assumption that 
students' meaning-making about their experiences in the LLC would be rooted in their previous experiences and perspectives as knowers. Consistent with case study design (Yin, 1984), data was gathered at different points and through different mechanisms.

Because of our interest in social justice understanding and LLC involvement and our suspicion that these might vary across students and communities based on different learning and reflection opportunities afforded to students, two frameworks informed the study. Broido's (2000) social justice ally development model depicts the process through which students advance to identify as social justice allies during their college experience. Central to the model are information sources (classes, connections to others, independent reading, travel) and reflection opportunities that help students clarify their positions on social justice issues and provide them confidence in their understanding social justice more deeply.

Astin's (1985) student involvement theory, which posits that student learning and development is proportional to students' level of involvement and resources provided by the institution promoting that involvement, also informed our perspectives. We specifically chose institutions we believed fostered varying levels of involvement when designing the study. We also believed that measuring involvement alone was insufficient to understanding students' experiences, thus, utilized both frameworks in our analysis.

\section{Data Collection}

Settings. Three social justice-themed living-learning communities located within private, Catholic postsecondary institutions served as settings for the study. We chose the Catholic context because we believed that the institutions would operationalize social justice in a similar manner, however we chose communities with different organizational elements and sizes to provide variation in our sample, so we might determine the extent to which different elements of the communities affected students' experiences (see table 1 for a summary of each community). We worked with university administrators who oversaw each community to gain access to the students in each community.

City University (CU) is classified by Carnegie as a large, four-year, highly residential doctoral research university located in the Midwest. CU's Social Justice Living-Learning Community (City LLC) was a sophomore community in which students lived on two floors in a residence hall (one all-male and one all-female), took one three-credit course together each semester for a year, and participated in three hours of service learning each week as part of their coursework. The service-learning office facilitated students' placement at service sites. Students selected a site most closely matching their interest from a list generated and provided by the office based on the staff's belief that the site centered justice in its service. The three credit courses could be counted 


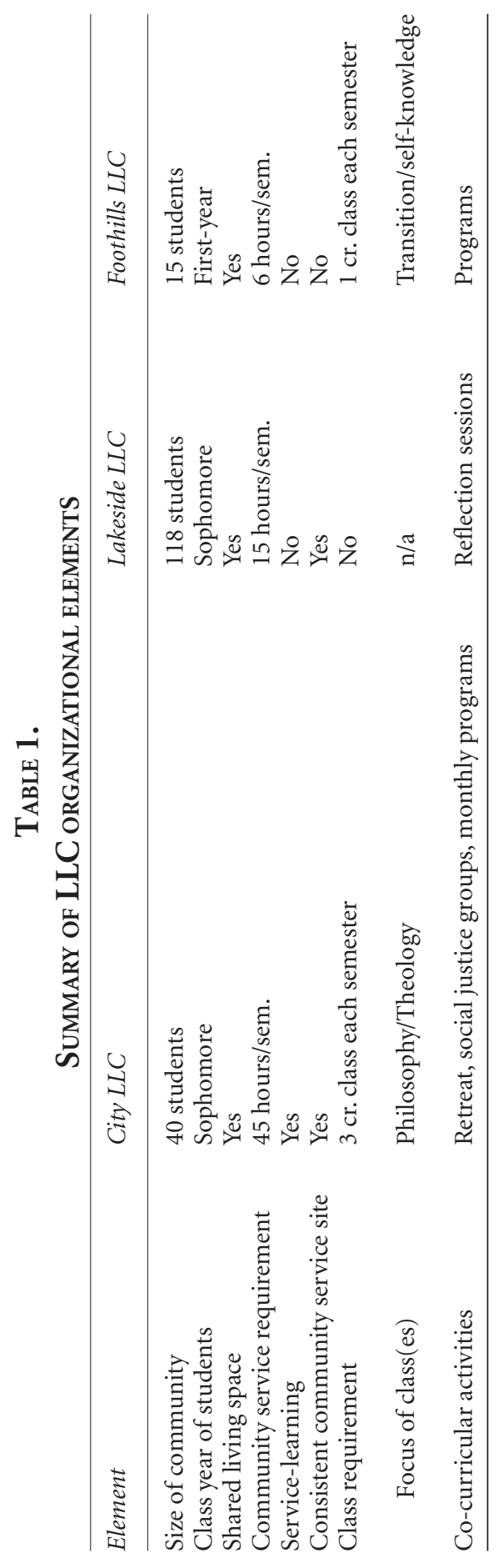


for students' required curriculum and included a philosophy course in the fall and theology course in the spring. Adjunct instructors taught both courses.

Lakeside College (LC) is a small, four-year, highly residential baccalaureate college located in the Midwest. LC's Social Justice Living-Learning Community (Lakeside LLC) was a sophomore community in which students lived together in eight-person suites in a residence hall and completed 15 hours of community service each semester at a site common to their suite. Marketing materials for the Lakeside LLC indicated that students with an interest "in community service and social justice can find a home" in the hall. Students applied to the community in groups of eight and ranked their community service site preferences upon application. A list of service sites was generated by staff based on the site's needs and willingness to accommodate students. Students indicated choosing a site based on their interests or convenience-if the site's hours matched their schedule or was close to campus to mitigate transportation concerns. There was no formal class connected with Lakeside LLC, however students participated in reflection sessions organized by the service-learning office at least once each semester.

Foothills College (FC) is a medium-size, four-year, primarily non-residential master's university located in the West. FC's Social Justice Living-Learning Community (Foothills LLC) was a first-year community in which students lived on two floors in a residence hall, took a one-credit course together for the entire year, and participated in 6 hours of community service outside of class each semester. Any service done by the community was done as a group and organized by the staff. The sites selected varied based on the connections of the director of the program. Marketing materials for Foothills LLC encouraged students to apply who were "academically, socially, and community minded" and who sought "more out of their first-year experience than the traditional route."

Participants. We drew a convenience, snowball sample from each of the communities, initially sending out an email inviting all students to participate, getting responses from some students, and then asking them to recommend others for us to talk to. We interviewed 10 students in City LLC, 14 students in Lakeside LLC, and 6 students in Foothills LLC. We stopped soliciting additional interviews when we were reasonably confident that we had saturated the sample (Seidman, 2012), and believed interviewing more people would not provide new information.

Overwhelmingly, our sample was comprised of Caucasian females (see table 2 for a summary of demographics). The racial demographics mirrored the demographics of the LLCs from which they were drawn, however, male students were underrepresented in the sample. Many students from City LLC and Foothills LLC went to service sites where they interacted with clients from different racial and ethnic backgrounds. 


\section{TABLE 2.}

\section{DEMOGRAPHIC DESCRIPTION OF SAMPLE}

\begin{tabular}{|c|c|c|c|c|}
\hline Pseudonym & $\operatorname{Sex}$ & Race/Ethnicity & Major & Community \\
\hline Andrea & Female & Caucasian & Political Science & CITY LLC \\
\hline Beth & Female & Caucasian & Social Welfare and Justice & CITY LLC \\
\hline John & Male & Caucasian & Biomedical Sciences & CITY LLC \\
\hline Preston & Male & Asian (Indian) & Business Administration & CITY LLC \\
\hline Rachel & Female & Caucasian & Psychology & CITY LLC \\
\hline Robert & Male & Caucasian & Communications & CITY LLC \\
\hline Sabriel & Female & Hispanic & Philosophy and English & CITY LLC \\
\hline Sandra & Female & Caucasian & Philosophy & CITY LLC \\
\hline Sue & Female & Caucasian & History \& Education & CITY LLC \\
\hline Zoey & Female & Caucasian & Political Science & CITY LLC \\
\hline Aaron & Male & Caucasian & Psychology & LAKESIDE LLC \\
\hline Alan & Male & Caucasian & Business Administration & LAKESIDE LLC \\
\hline Christine & Female & Caucasian & Business Administration & LAKESIDE LLC \\
\hline Dan & Male & Caucasian & Graphic Design & LAKESIDE LLC \\
\hline Deborah & Female & Caucasian & Accounting & LAKESIDE LLC \\
\hline Dirk & Male & Caucasian & Education and Psychology & LAKESIDE LLC \\
\hline Kalin & Female & Caucasian & Business Administration & LAKESIDE LLC \\
\hline Kelly & Female & Caucasian & Communications & LAKESIDE LLC \\
\hline Laurie & Female & Caucasian & Communications \& French & LAKESIDE LLC \\
\hline Lisa & Female & Caucasian & Accounting & LAKESIDE LLC \\
\hline Lucy & Female & Caucasian & Business Administration & LAKESIDE LLC \\
\hline Mandy & Female & Caucasian & Communications & LAKESIDE LLC \\
\hline Martin & Male & Caucasian & Accounting & LAKESIDE LLC \\
\hline Rose & Female & Caucasian & Business Administration & LAKESIDE LLC \\
\hline Allie & Female & Caucasian & Undecided & FOOTHILLS LLC \\
\hline Elizabeth & Female & Caucasian & Nursing & FOOTHILLS LLC \\
\hline Harper & Female & Caucasian & Nursing & FOOTHILLS LLC \\
\hline Molly & Female & Caucasian & Sociology & FOOTHILLS LLC \\
\hline Ramona & Female & Caucasian & Sociology & FOOTHILLS LLC \\
\hline Sage & Female & Caucasian & Undecided & FOOTHILLS LLC \\
\hline
\end{tabular}

Interviews. The first and third authors conducted semi-structured interviews with students during their second semester in the community. Our interviews were guided by Broido's (2000) social justice framework and Astin's (1984) involvement framework in addition to our constructivist (Broido \& Manning, 2002) perspective, which recognized the interdependence and subjectivity of our relationship with participants, necessitating mutuality in our meaning-making about participants experiences. We asked questions to elicit students' perceptions of their LLC environment and its role on their understanding of social justice and LLC involvement. We also were guided by existing literature, which illustrated that LLCs may help to foster peer interaction (Inkelas \& Weisman, 2003) and faculty/student interaction (Cox \& Orehovec, 2007). Our interviews were comprised of general questions 
about their experience and definition of social justice, specific questions about relationships with peers in the community, experiences with community service, and discussions about their LLC involvement with others in and outside the LLC. For students in City LLC and Foothills LLC, whose communities included a class component, we asked questions about their experiences in class. For students in Lakeside LLC, we asked them about mandatory reflection sessions. We also asked students about their involvements outside the LLC to get a sense of the scope of their involvement in relation to other aspects of their lives. Each interview lasted between 15 and 75 minutes, with the average interview lasting 55 minutes.

Other data sources. We collected students' applications to their livinglearning communities to contextualize their expectations and goals for participating in the communities and ensure these were somewhat similar across communities despite the different elements of each community. In addition, we examined the webpages advertising the communities to get a sense of what may have attracted students to these communities and whether students' descriptions of their experiences matched what was advertised about the communities. The information gathered was used to confirm that the elements we believed were offered in the communities based on website descriptions matched students' descriptions of the communities.

\section{Limitations}

Before we depict our analysis and findings, it is important to address some limitations of our study. First, despite our attempt to recruit a representative sample, ours is overwhelmingly white and female. Although the sample mirrors the demographic of the LLCs, we wondered whether the absence of reflection across demographic differences may have been a product of who we interviewed. In addition, because of the constructed nature of the study design, we are not able to claim with certainty the relationship between LLC elements and student outcomes, rather rely on students' depiction of their experiences and environments to identify the important elements of the community.

\section{Trustworthiness and Analysis}

We took several steps to ensure trustworthiness of the qualitative research process (Creswell, 2007), including transcribing all interview data verbatim, sending synopses of the interview back to participants to ensure accurate representation, corroborating participants' responses with interview notes, and discussing results of the data with colleagues. Our third author served as an inquiry auditor (Lincoln \& Guba, 1985), examining the analysis, findings, and interpretations to ensure they were supported by the data.

We used a constant comparative method (Lincoln \& Guba, 1985) to analyze the data and draw themes. The first two authors read through each 
of the transcripts independently, paying attention to students' description of their experiences in these communities, particularly related to social justice understanding and LLC involvement. After determining that students demonstrated substantial variation in their understanding of social justice and LLC involvement, we created rubrics for each of these concepts to see if living-learning community specific patterns emerged (see the top row of figures 1 and 2 for the criteria for each category). Our social justice understanding rubric was informed by Broido's (2000) social justice ally development (discussed earlier), which illustrated that students must have awareness of social inequity, opportunities for reflection related to inequity, and opportunities to engage in addressing inequity to become social justice allies. Our involvement rubric was informed by Astin's (1984) involvement theory, which posited that involvement requires an investment of psychological and physical energy, and the gains from being involved are proportional to the extent of involvement (in quantity and quality). On the bottom row of figures 1 and 2, we provide an exemplar of each category from our interview transcripts. Finally, to determine the patterns of community, social justice understanding, and LLC involvement, we plotted the scores from each of the rubrics onto a graph (see figure 3 ). If more than one student from a community plotted onto the same point, we increased the size of the point to illustrate the potential influence of the community.

\begin{tabular}{|c|c|c|c|}
\hline No Involvement $(-2)$ & Superficial (-1) & Adequate (1) & Distinguished (2) \\
\hline $\begin{array}{l}\text { Student attends to a } \\
\text { few of the } \\
\text { requirements of the } \\
\text { community, does not } \\
\text { reflect on experience } \\
\text { in community and } \\
\text { does not describe } \\
\text { learning from others. }\end{array}$ & $\begin{array}{l}\text { Student attends to most } \\
\text { of the requirements of } \\
\text { the community and } \\
\text { demonstrates minimal } \\
\text { reflection on experience } \\
\text { and learning from } \\
\text { others }\end{array}$ & $\begin{array}{l}\text { Student attends to all the } \\
\text { requirements of the } \\
\text { community; reflects on } \\
\text { experience in } \\
\text { community; and } \\
\text { describes learning from } \\
\text { and with others }\end{array}$ & $\begin{array}{l}\text { - Student attends to all } \\
\text { the requirements of the } \\
\text { community, reflects } \\
\text { deeply on experience } \\
\text { in community and } \\
\text { describes learning from } \\
\text { and with others. } \\
\text { - Student demonstrates } \\
\text { leadership within the } \\
\text { community by } \\
\text { engaging with others } \\
\text { and encouraging others } \\
\text { involvement }\end{array}$ \\
\hline $\begin{array}{c}\text { No Involvement } \\
\text { Exemplar }\end{array}$ & Superficial Exemplar & Adequate Exemplar & $\begin{array}{c}\text { Distinguished } \\
\text { Exemplar }\end{array}$ \\
\hline $\begin{array}{l}\text { Described "not really } \\
\text { being motivated to go over } \\
\text { to [service site] because } \\
\text { there is nothing to do } \\
\text { there" and when asked } \\
\text { about reflection, described } \\
\text { it as "pointless" (Dan) }\end{array}$ & $\begin{array}{l}\text { "I feel like I just do what I } \\
\text { have to do to finish my } \\
\text { segment in the [LLC], but } \\
\text { sometimes I don't know if } \\
\text { I am truly committed to, } \\
\text { like... like I wouldn't give } \\
\text { up my life to help others. } \\
\text { After college I am not } \\
\text { going to go to the Peace } \\
\text { Corps. I don't understand } \\
\text { others' drive to do that. } \\
\text { (Sabriel) }\end{array}$ & $\begin{array}{l}\text { "I would love to do more } \\
\text { [volunteering and } \\
\text { organizing events], but my } \\
\text { schedule unfortunately } \\
\text { doesn't allow for it. So, I } \\
\text { try to allot all the time I } \\
\text { possibly can and support } \\
\text { others' [efforts] while still } \\
\text { being able to focus on my } \\
\text { job and school. I almost } \\
\text { wish I had more time to } \\
\text { commit...I learn a lot." } \\
\text { (Robert) }\end{array}$ & $\begin{array}{l}\text { "Sometimes I challenged } \\
\text { [my peers] to commit } \\
\text { more [to the community] } \\
\text {...I feel like our } \\
\text { commitment levels have } \\
\text { varied between moderate } \\
\text { and high. ... We feed off } \\
\text { one another just by what } \\
\text { we do. If we like some } \\
\text { [social justice-oriented } \\
\text { club or event], we tell } \\
\text { others about it and invite } \\
\text { them to join us." } \\
\text { (Preston) }\end{array}$ \\
\hline
\end{tabular}

Figure 1. Social Justice LLC Involvement Criteria and Exemplars 


\begin{tabular}{|c|c|c|c|}
\hline No Evidence $(-2)$ & Emerging $(-1)$ & Advancing (1) & Distinguished (2) \\
\hline $\begin{array}{l}\text { No evidence of } \\
\text { awareness of societal } \\
\text { inequity; } \\
\text { No evidence of } \\
\text { awareness of the role } \\
\text { of social and societal } \\
\text { structures in } \\
\text { maintaining inequity; } \\
\text { - No commitment to } \\
\text { action to address } \\
\text { societal inequity }\end{array}$ & $\begin{array}{l}\text { Superficial awareness } \\
\text { of societal inequity; } \\
\text { No awareness of the } \\
\text { role of social and } \\
\text { societal structures in } \\
\text { maintaining inequity; } \\
\text { No or superficial } \\
\text { commitment to address } \\
\text { societal inequity }\end{array}$ & $\begin{array}{l}\text { - Demonstrated awareness } \\
\text { of societal inequity; } \\
\text { - Superficial awareness of } \\
\text { the role of social and } \\
\text { societal structures in } \\
\text { maintaining inequity; } \\
\text { - Clear commitment to } \\
\text { personally addressing } \\
\text { societal inequity }\end{array}$ & $\begin{array}{l}\text { Clear articulation of } \\
\text { societal inequity and } \\
\text { the role of social and } \\
\text { societal structures in } \\
\text { maintaining and } \\
\text { exacerbating inequity; } \\
\text { Clear commitment to } \\
\text { working in solidarity } \\
\text { with others to address } \\
\text { societal inequity }\end{array}$ \\
\hline No Evidence Exemplar & Emerging Exemplar & Advancing Exemplar & Distinguished Exemplar \\
\hline $\begin{array}{l}\text { "Being nice to people and } \\
\text { treating them equally." } \\
\text { (Dan) }\end{array}$ & $\begin{array}{l}\text { "When I think social } \\
\text { justice, I think social } \\
\text { consequence. I kind of } \\
\text { think about judging... } \\
\text { [pause]. Social justice. } \\
\text { Justice. I guess you could } \\
\text { look more in depth - I } \\
\text { might totally be on the } \\
\text { wrong track. Like is it } \\
\text { socially just that some } \\
\text { people have all this } \\
\text { money, and they can } \\
\text { spend it, you know what I } \\
\text { mean? They can buy a } \\
\text { \$300 pair of jeans, } \\
\text { whereas some people, } \\
\text { maybe at [the service } \\
\text { site], can't even afford a } \\
\text { turkey for Thanksgiving." } \\
\text { (Lucy) }\end{array}$ & $\begin{array}{l}\text { "I would define social } \\
\text { justice as examining } \\
\text { critically the problems in } \\
\text { the world and looking } \\
\text { for a way to either find a } \\
\text { solution or help to curb } \\
\text { them, be that through } \\
\text { volunteering or } \\
\text { awareness." (Robert) }\end{array}$ & $\begin{array}{l}\text { "Social justice is a } \\
\text { commitment toward } \\
\text { working for social change, } \\
\text { not just hoping to solve a } \\
\text { small problem or giving to } \\
\text { charity, but actually trying } \\
\text { to change the structure of } \\
\text { society so that it betters } \\
\text { the people in it. ...there is } \\
\text { a distinction between } \\
\text { charity and social justice. } \\
\text { [In] seeking how to do } \\
\text { social change...I am able } \\
\text { to realize how to change } \\
\text { the structure and recognize } \\
\text { the problems within the } \\
\text { system." (Preston) }\end{array}$ \\
\hline
\end{tabular}

Figure 2. Social Justice Understanding Criteria and Exemplars

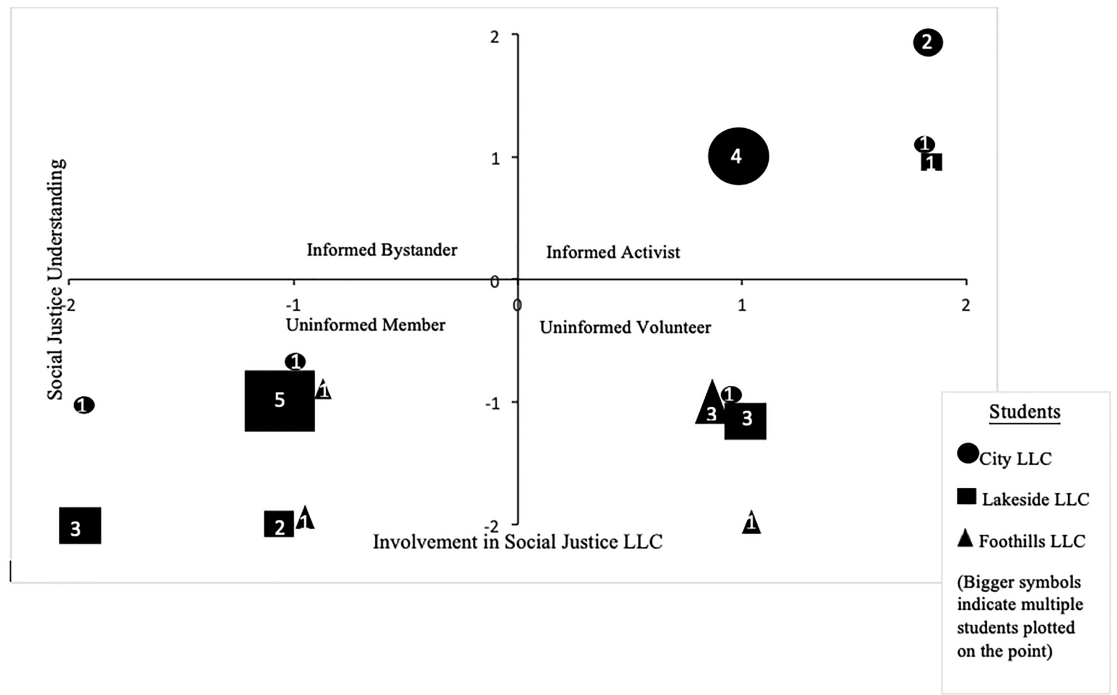




\section{FINDINGS}

As illustrated by figure 3, when we plotted students' LLC involvement and social justice understanding onto a graph, patterns emerged that provided information about each of the communities. For example, overwhelmingly students in City LLC demonstrated adequate or distinguished LLC involvement and advancing or distinguished understanding of social justice, whereas most students in Foothills LLC demonstrated being adequately or highly involved in the LLC but no or emerging evidence of social justice understanding. Most students in Lakeside LLC neither exhibited adequate or distinguished LLC involvement nor social justice understanding. We provide a composite of students in each quadrant below with supporting evidence from our data. Then we examine the various aspects of the communities that may have contributed to these differences.

\section{Student Characteristics}

We used the graph depicted in figure 3 to develop a composite of students in each quadrant. We labeled the quadrant based on students' LLC involvement and social justice understanding scores-Informed Activist, Uninformed Volunteer, Uninformed Member, and Informed Bystander. We describe these below beginning with the Informed Activist quadrant and moving clockwise through the graph.

Informed Activist. We used the term informed activist to depict students who exhibited both engagement in their LLC and social justice understanding. Of the eight students who we labeled as Informed Activists, seven were from City LLC and one was from Lakeside LLC. Four of them (Preston, Sue, Andrea, and Laurie) demonstrated distinguished involvement, recounting instances where they engaged with others and encouraged their involvement. We used Preston as an exemplar for distinguished involvement (see figure 1, distinguished involvement), as he described being deeply involved in the LLC and encouraging others' involvment as well.

The students who we classified as adequate in their involvement (Beth, John, Robert, and Zoey) expressed a lack of time and competing commitments as reasons they were not more involved. John characterized his involvement in the LLC as "smack dab" in the middle, explaining that he was more of a participant than a "driving force" of the community. He explained that his intention in joining the LLC was to do more community service, a goal which he believed he was reaching. Others, he posited were more "gung ho," because they were Social Justice majors or minors who had more of a vested interest in leading their peers to live in more socially just ways. Both Robert and Zoey mentioned time as a factor that kept them from a deeper commitment to the community. Like Beth and John, Robert and Zoey believed they were attending to all the requirements of the community, but work and other 
classes got in the way of "going above and beyond." Robert recounted the time crunch he encountered (see figure 1, adequate involvement exemplar).

In addition to their adequate or distinguished involvement in their LLC, Informed Activists demonstrated distinguished (Preston, Sue) or advancing (Andrea, Beth, John, Laurie, Robert and Zoey) social justice understanding. Preston's definition of social justice clearly illustrated the connection he saw between social justice and societal structures as well as his role in addressing social justice issues (see figure 2, distinguished social justice understanding exemplar). Sue identified social inequality and social structures in her definition but put much of her emphasis on personally addressing social inequity. She explained,

I [think about] how I can respond to [injustice] and how I can improve this injustice and make it more just, or how am I called to act in response to this [injustice]. But it's more than just tutoring... It's more than just giving food to someone at a soup kitchen. It's the relationships, and the people, and why is that person homeless. Those sorts of things that I think [City LLC] pushes me to examine and answer and think more deeply about.

Students who were advancing in their social justice understanding demonstrated awareness of societal inequality and a commitment to personally addressing it, however, their understanding of the role of social and societal structures in maintaining inequity was superficial. Robert's definition illustrates this superficiality (see figure 2, advancing social justice understanding exemplar). And, even though she was in a different LLC, Laurie's definition was markedly similar to Robert's. After some apprehension, Laurie explained,

I don't, oh gosh, I don't know. I guess [Social justice] it's just everybody like, should be allowed to have the same rights, like, kids should be allowed to go to school, and if they don't have a place to go after school, there should be a place to go. And there should be tutors available for them to learn how to read and learn all their different kind of school things they need to know. I feel like everybody deserves that same kind of chance-that education and success in this life in general.

Uninformed Volunteer. We labeled students who demonstrated adequate involvement in their LLC community but lacked meaningful social justice understanding as uninformed volunteers. These students attended to all the requirements of the community, reflected on their experiences, and described learning with or from others. Of the eight students who we labeled Uninformed Volunteers, four were from Foothills LLC, three were from Lakeside LLC, and one was from City LLC. Seven of them (Allie, Harper, Lisa, Lucy, Kalin, Molly, and Rachel) demonstrated emerging evidence of social justice understanding, whereas one (Sage) demonstrated none. 
Uninformed Volunteers participated enthusiastically in their LLCs. Several of them credited their LLC with helping them to become "more accountable for their actions" (Allie) and deepening their value for service (Molly, Harper, and Sage). Both Allie and Harper discussed their disappointment that the service requirement was not heavy and were hopeful that the administration might increase the service requirement. For students in Lakeside LLC (Kalin, Lisa, and Lucy), the service requirements were "doable." Kalin explained that her connection with the girl she was mentoring was what kept her involved. "She tells me a lot of stuff and trusts me now."

Despite their adequate involvement in their social justice LLCs, Uninformed Volunteers demonstrated superficial awareness of and commitment to addressing social and societal inequity and lacked understanding of the role of social structures in maintaining inequity. When asked about their definitions of social justice, several students struggled to find the words to define it, and after they did, looked for validation that their definition was right. Lucy struggled to find the words to describe social justice (see figure 2, emerging exemplar). Other students in Lakeside LLC equated social justice with fairness and equality. Kalin described social justice as "everyone getting what they deserve equally." When pressed how that might happen, she stated, "fixing the difference between people, and having people get what they deserve, and having everyone equally happy."

The students in Foothills LLC equated social justice with service. Harper and Allie explained that social justice means being a good person, which is often evident by the service one does. Molly echoed their thoughts, explaining that her experience in the community helped her combat feelings of not wanting to do service because her peers made it fun.

Rachel, the one student from City LLC who was an Uninformed Volunteer, differed from her peers in City LLC in that she failed to connect the notion of social justice to societal inequity and social structures. She viewed social justice as synonymous with education, stating, "[Social justice is] being committed about an issue and taking an active role in making the issues more aware to the whole community." When asked how the experience changed her, if at all, Rachel indicated that it gave her a social network. She explained, "I like having the community setting and doing projects and social events with both floors is beneficial...I think [my experience in the LLC] is a lot better to meet people...that's very beneficial."

Uninformed Member. Uninformed Members were labeled such because they demonstrated superficial or no involvement in their LLC community and provided emerging or no evidence of social justice understanding. Of the fourteen students we labeled as Uninformed Members, two were from City LLC, two were from Foothills LLC, and ten were from Lakeside LLC. Ten (Alan, Christine, Deborah, Elizabeth, Kelly, Mandy, Martin, Ramona, 
Rose, and Sabriel) demonstrated superficial involvement, discussing how they met the minimum requirements of the community and demonstrating minimal reflection and learning from their experiences. Alan, Christine, Deborah, Kelly, Mandy, Martin, and Rose (all of whom were from Lakeside LLC) discussed conversations with their suitemates about their experiences, but these conversations were superficial. For example, Rose shared how her suite would talk about what they did at their service site or would discuss what they liked and did not like. Christine mentioned a reflection session organized by the service-learning department but explained that her greatest take away from the session was "what it is like to live with eight other people" as opposed to learning anything from her service site. Sabriel, who was in City LLC, possessed a deeper understanding of social justice than some peers in other communities, however, she indicated a lack of respect for others' perspectives and minimal reflection (see figure 1, superficial exemplar).

On the low end of the involvement continuum were four students who demonstrated no involvement in their learning communities. Three of these students were from Lakeside LLC (Aaron, Dan, and Dirk). They discussed missing their service obligations because of a lack of motivation (see figure 1 , no involvement exemplar), other priorities (Aaron) or a feeling that they weren't really needed at their site (Dan, Dirk). Sandra was the only student from City LLC who exhibited no involvement in her LLC. She explained that she was not taking the mandatory class because she joined the community late and had already met the requirement. She also skipped her service-learning requirements because she did not like the site and her responsibilities there.

Along with their paltry involvement, Uninformed Members also demonstrated emerging or no evidence of social justice understanding. Seven of them (Alan, Christine, Elizabeth, Mandy, Martin, Rose, Sabriel, and Sandra) possessed superficial awareness of social and societal inequity, a superficial commitment to addressing such inequity, and lacked awareness of the role of social and societal structures in maintaining inequity. Christine explained social justice by comparing her own life to the life of the child she was mentoring. She explained,

I've learned a lot more about different lifestyles and how other people grow up and stuff.... [My mentee's] parents are divorced. My parents are not divorced... I didn't even think about money [at her age] and she talks about that a lot...."

Despite these reflections, Christine had difficulty defining social justice, or even explaining why there were differences between her background and the child's:

Social justice is everything, just like, everything being-like equality. A line of equality and no perks or reprimands for any certain type of person. 
On the low end of the social justice understanding continuum were six students, one from Foothills LLC (Ramona) and five students from Lakeside LLC (Aaron, Dan, Deborah, Dirk, and Kelly), who demonstrated no evidence of social justice understanding. Ramona made no attempt to define social justice. Instead, she talked about the shared vocabulary she gained from her experience in Foothills LLC. Some of the Lakeside LLC students connected social justice to living in a suite, while others had only a vague notion of what social justice might be. For example, when asked to expand on his definition of social justice, Aaron applied "what's fair in a social setting," to his suite, explaining that even though "we're all crazy, we always still look out for each other's safety and well-being." Dan was also vague, describing social justice as "being nice to people and treating them equally" (see figure 2 , no evidence exemplar) whereas Dirk described it as "an eye for an eye leaves the whole world blind." When pressed to apply the phrase, Dirk shrugged it off, noting that he didn't really know.

Informed bystander. As noted in figure 3, we did not classify any of the students in the study as informed bystanders. Their absence resulted from the way we opted to define social justice understanding. Because social justice understanding necessitated demonstrating a commitment to addressing social and societal inequity, there was an involvement element embedded in our definition, thus all participants who scored advancing or distinguished in their social justice understanding were, by definition, at least adequately involved in their LLCs.

\section{Contextual factors}

Based on the patterns of variation by community, with students from City LLC dominating the informed activist quadrant, students from Foothills LLC dominating the Uninformed Volunteer quadrant, and students from Lakeside LLC dominating the Uninformed Member quadrant, we examined the contextual factors of the communities for clues as to why the patterns emerged. Each of the communities offered different opportunities for student engagement, with variation in courses, reflection opportunities, support from staff, and the interactions with community peers, which influenced the extent of students' engagement and social justice understanding.

Apart from the one student from Lakeside LLC, students in the Informed Activist quadrant noted extensive support from their LLCs, including a community retreat, philosophy and theology courses, and in- and out-of-class, structured reflection time that addressed students' community service. These students took advantage of the opportunities provided, and some sought out additional opportunities. For City LLC, the class was a key aspect of their experience. Students took a philosophy class in the fall and a theology class in the spring, both with only peers from the LLC. The courses were taught by two faculty members who engaged with the community beyond the 
classroom, including attending the fall retreat. The classroom provided an outlet for students to reflect on their community service work and connect experience to concepts in their readings and discussions. When reflecting upon the spring theology course, Robert noted,

We get into some very good discussions and [the professor] does a very good job of giving us a lot of time to discuss things without her really getting involved in it. It's nice that we can kind of speak freely and she can give input.

The class encouraged students to engage in constructive dialogue around social justice issues and make connections to the broader society.

Additionally, students living in City LLC partook in frequent reflections surrounding issues of social justice. Students often discussed the impact of their actions. John explained,

We have groups that we're supposed to focus on one kind of issue during reflections and floor meetings. And then we're supposed to get together with other people at our site and do a project that benefits our site.

City LLC encouraged students to go beyond simply doing service to reflect actively on that service and work toward understanding social justice.

In contrast, although students at Lakeside LLC were required to do service, their reflections on their service were minimal. Laurie, the only student from Lakeside LLC in the Informed Activist quadrant, appeared frustrated by the lack of engagement by her peers. She noted that the reflections lacked the structure to engage in deeper discussion.

I feel like [my peers] just didn't take it very seriously... they were like laughing through the whole thing.

Although Laurie attempted to engage with her experiences through formal reflection, the loose structure prohibited thoughtful engagement. The culture of the community was not conducive to a meaningful experience.

Another important element of City LLC was the support found amongst peers. Supportive relationships formed within community classes and service sites and existed outside of structured forums. When discussing the unique support found within the living learning community, Sue explained,

Some of us have developed really close friendships and having that opportunity to discuss some of our service sites, whether they're ones associated with our experience on the floor or outside of that or just different social justice issues... those kind of ideas and people that share those same viewpoints is nice to have that community feel....

Ultimately, the intersection of the LLC courses, required community reflection, and peer engagement of social justice issues created a commu- 
nity conducive to both involvement within the community and a deepened understanding of social justice. Because City LLC was the only of the three communities that maintained all elements, it makes sense that most students from there were Informed Activists.

Students in the Uninformed Volunteer quadrant were also highly involved in their communities but demonstrated less social justice understanding. Four of the students in this quadrant were from Foothills LLC, which also included a required course component. The course, however, was a onecredit seminar focused on helping students adjust to college, with some explanation of Jesuit values, as opposed to deep disciplinary content such as philosophy or theology. The difference in course structure and content may have resulted in superficial social justice understanding. Sage provided some insight on the benefit of Foothills LLC for social development. She explained, "we've learned so much about ourselves and our own values and it's been strengthened by other people and also, like, having it challenged by other people strengthens it even more." Harper, however, expressed her disappointment on the structure of the community.

For one, having the class not be what I expected and then, two, not even having that heavy service component, which was like a big chunk of the reason why I applied, is sometimes frustrating because it's like, 'I have the time. I want it.'

The Uninformed Volunteers from Lakeside LLC also provided some insight into how their community facilitated and impeded their involvement and social justice understanding. Because Lakeside LLC did not offer an academic course, students were not compelled to interact outside their suites, nor did they reflect deeply on their service-learning experiences or connect it to academic content. Lisa provided insight into the reflection sessions.

We pretty much just tell about what's been happening at the site, what we do on a daily basis-I don't know if the [sessions] necessarily needed. I think that when we get into these meetings we end up just all saying the same thing over again.

Rachel, the sole student from City LLC in the quadrant, had strong contextual support from her living learning community. However, she continually mentioned her lack of class engagement and unwillingness to share her perspective with peers.

Students in the Uninformed Member quadrant either did not discuss their communities as supporting their LLC involvement and social justice understanding or described opting not to engage in the opportunities provided, indictating a lack of desire to reflect on their service. For example, although they engaged in service, the Uninformed Members from Lakeside LLC focused mostly on their peer group social interactions. Alan noted 
"You feel together as part of a group, like connected with each other." Other students, like Christine, echoed this sentiment, discussing how she gained the most from becoming

Aware of what it's like to live with eight other people. That definitely has opened my eyes to being respectful toward other people...I've become more open and comfortable with newer people.

The lack of common course and limited opportunity for reflection ultimately led to a mostly unengaged community. Kelly illustrated the superficial reflection that took place.

I think [in the first reflection] we just kind of talked about like our experiences. And then the second one we went in the chapel and we watched this video about continuing [community] service, because like how much more blessed we are than a lot of other people in the world.

Students in Foothills LLC reported that the community facilitated greater intrapersonal and interpersonal development than involvement in the community or deepened their understanding of social justice. Elizabeth discussed being more aware of serving for "the glory of God" because of the content of the course whereas Ramona discussed the friendships she developed because of her interactions on the floor.

The Uninformed Members from City LLC provide evidence that even when structural elements are present, students' exemptions from those elements or resistance to engagement can thwart involvement and development of social justice understanding. Sandra was exempt from taking the required course, and thus did not routinely attend her service learning requirements nor engage formally with her peers about service. Sabriel, on the other hand, attended to the minimal requirements of the LLC, but her dislike of her service site impeded her from full involvement and social justice understanding. She explained her frustration about doing intake at a homeless shelter: "I don't want to go [to my site] anymore, because I don't want to sit there and take names.... technically they can't force me to, but [when I protest] they are like, 'this is all we have for you."'

In summary, strong patterns existed when considering students' involvement in a social justice living learning community and understanding of social justice. Most students who experienced high levels of both LLC involvement and understanding of social justice had a more formal structure within their community, whereas most students low in both areas noted the absence of structure. 


\section{DisCUSSION AND IMPLICATIONS}

Our findings show the importance of context and institutional resources in supporting students' social justice understanding and LLC involvement. Involvement alone was insufficient to promote social justice understanding, and in fact, sometimes students' involvement without meaningful reflection reinforced stereotypes at students' service sites. However, students' social justice understanding deepened when involvement was supplemented with sustained learning opportunities in the form of classes, structured reflection about community service, and sustained discussions about justice. The patterns of students' social justice understanding and LLC involvement across the communities illustrate that the elements of each community played an important role in whether students demonstrated these outcomes. With some exceptions, students in more comprehensively resourced communities exhibited greater social justice understanding and LLC involvement, a finding that extends Wawrzynski and Jessup-Anger's (2010) quantitative study by providing a more holistic portrait of why resources matter by illustrating that such elements as a credit-bearing class that focused on social justice, coupled with sustained service in a justice-related site helped to deepen students' understanding of social justice. These findings support the anecdotal observations made by Watterson, Rademacher, and Mace (2012) regarding the importance of challenging, discipline-centered coursework that purposefully connect service-learning in providing students with coherence and engagement in pluralism because it provides students with theoretically-grounded definitions and content in which to contextualize their experiences. The findings help to contextualize Rowan-Kenyon, Soldner, and Inkelas's (2007) findings that students living in civic participation-focused LLCs exhibited stronger civic engagement, but not after pre-dispositions were considered. As our findings illustrate, the elements of the community affect outcomes greatly, and thus a civic engagement LLC alone is unlikely to bring about such an outcome.

When taken together, the findings about the importance of having both a well-resourced LLC and students who are willing to engage in that community add gradation to the high-impact practice discussion (AAC\&U, 2007), as the findings illustrate that merely grouping students together who have a shared interest in social justice and providing avenues for them to do service is insufficient to realizing the outcomes learning communities promise as a high impact practice. Instead, faculty and student affairs educators must identify students who are willing to engage in the community, help them to connect to a site they are passionate about, and provide them with opportunities for academic engagement about their communities, meaningful reflection, and meaningful community involvement. 
In light of our findings, we have several recommendations for faculty and student affairs educators who strive to create social justice LLCs that reach their potential as a high impact practice (AAC\&U, 2007). First, ensure that the LLC is connected to one or more challenging, relevant academic courses. A challenging course promotes critical thinking and signals to students that they should take the course seriously. Moreover, it may encourage students to partner with their peers to learn the material, deepening students' interactions with one another. Our findings illustrated that one of the aspects of the community that set apart Informed Activists (and particularly those from City LLC) from other students were their academic interactions with peers. These students also drew upon their course material to demonstrate their social justice understanding and referred to their classes as challenging them to think more deeply about social justice issues. In contrast were students in Foothills LLC; although they had a course connected to their learning community, they did not engage in the course material with peers nor demonstrate understanding of social justice issues. The difference in these outcomes may be explained by the differences in the courses connected to the communities. City LLC's courses were part of the university curriculum, were taught by faculty, were described by students as rigorous, and were directly connected to the social justice outcomes of the community. Foothills LLC's class, on the other hand, was more oriented toward helping students adjust to college and articulate their values. Although perhaps helpful for the college transition, the course did not serve to advance their social justice understanding. Assuming an LLC relates to academic outcomes, a challenging and relevant academic experience is essential for students.

Second, ensure that there are multiple layers of engagement for students who have varying levels of commitment to the community. Whereas those Informed Activists (particularly those from City LLC) with distinguished involvement articulated their role in helping the community flourish, other students did not have a sense of agency to provide leadership in their communities, and thus resorted to guilting their peers into participating in the community, which led to frustration and resentment. By providing different opportunities for involvement, including leadership positions coupled with relevant on-going and one-time activities, students can engage in the community to the extent that they desire.

Third, ensure that faculty and staff who interact with the community are adequately trained to guide reflection that helps students connect to the community with whom they are working, unpack and unlearn stereotypes they hold, and identify the structural elements that impede social justice. When done well, we found that reflection served as a space for students to challenge their assumptions and engage with their experiences both in service and the greater context of social justice work. However, students also reported a lack 
of depth and focus in their reflection sessions. Lakeside LLC's student-led service learning team lacked the capacity to work effectively with reluctant reflectors to keep them on task and make meaningful connections between their sites and social structures. Better trained facilitators could increase the breadth and depth of students' reflection about their experiences in the living-learning community and social justice work.

Finally, find community service sites where students can contribute in meaningful ways so that they feel like their work matters (Schlossberg, 1989). Among the recommendations for fostering service learning partnerships advanced by Jacoby (2015) is clear communication by the site and the university to ensure that there is compatibility. Establishing open dialogue about the priorities of the site and how students might address them is essential. Asking questions like what skill levels, time commitments, and resources are necessary for students to be successful in advance of creating a partnership will ensure that students can fulfill the site priorities. Furthermore, Jacoby (2015) encourages ongoing attention be paid to assessing the outcome of the partnership to ensure learning and community impact. These steps can ameliorate the reality that we saw in our data, namely that some of the most disengaged students reported feeling that they were not needed at their community service sites and were less inclined to attend to the requirements of the community. In an LLC, feeling marginal in one aspect of the community can have a ripple effect into other aspects of the community, as all the elements are intertwined.

\section{ConcLusion}

After exploring the LLC involvement and social justice understanding of students across three different living-learning communities, it is clear that the presence of a community alone is not enough to foster the transformation necessary to help students address society's most pressing needs (National Task Force on Civic Learning and Democratic Engagement, 2012). Institutions must invest time, energy, and resources to ensure that students develop the capacity for social justice understanding. By providing motivated students with challenging courses, opportunities to participate in and reflect meaningfully on community service, and other engage in structured activities that encourage their community participation, these students are more likely to develop into Informed Activists and advance their capacity for community engagement. In the absence of sufficient resources to design, deliver, and sustain a social justice LLC, institutional leaders must grapple with the decision to house a community at all. As illustrated in our study, when these communities are poorly resourced, inadequately staffed, or not connected to faculty and coursework, they may reinforce stereotypes and engender resentment by students involved in them. 
Future research on the LLC involvement and social justice understanding might take two forms: it could focus on exploring the interactions and synergies of various dimensions in the LLC environment (courses, student interactions, community service sites, reflection sessions) to understand more about how they invoke social justice understanding and LLC involvement. Additional research is also needed to determine the impact of high functioning communities over time. After students leave these intense experiences, do they remain engaged in bettering their communities? Does their social justice understanding continue to develop? How do successful communities incentivize faculty involvement? Additional research is needed to know whether the substantial resources needed for these communities to be successful is worth the investment.

\section{REFERENCES}

Association of American Colleges and Universities. (2007). College Learning and the New Global Century. Washington, D. C. Author.

Astin, A. W. (1984). Student involvment: A developmental theory for higher education. Journal of College Student Personnel, 25, 297-308.

Boyle-Baise, M. \& Langford, J. (2004). There are children here: Service Learning for Social Justice. Equity \& Excellence in Education, 37(1), 55-66.

Broido, E. M. (2000). The development of social justice allies during college: A phenomenological investigation. Journal of College Student Development, $41(1), 3-18$.

Cox, B. E., \& Orehovec, E. (2007). Faculty-student interaction outside the classroom: A typology from a residential college. Review of Higher Education, 30(4), 343-362.

Creswell, J. W. (2007). Qualitative inquiry and research design: Choosing among five approaches ( $2^{\text {nd }}$ ed.). Thousand Oaks, CA: Sage.

Einfeld, A., \& Collins, D. (2008). The relationships between service- learning, social justice, multicultural competence, and civic engagement. Journal of College Student Development, 49, 95-109.

Inkelas, K. K., \& Weisman, J. L. (2003). Different by design: An examination of student outcomes among participants in three types of living-learning programs. Journal of College Student Development, 44, 335-368.

Jacoby, B. (2015). Service learning essentials: Questions, answers, and lessons learned. San Francisco, CA: Jossey-Bass.

Kuh, G. D. (2008). High-impact educational practices: What they are, who has access to them, and why they matter. Washington, DC: Association of American Colleges \& Universities.

Lincoln, Y., \& Guba, E. (1985). Naturalistic inquiry. Beverly Hills, CA: Sage.

Matthews, R. S., Smith, B. L., \& MacGregor, J. (2012) The evolution of learning communities: A retrospective. In K. Buch \& K. E. Barron (Eds.), Discipline centered learning communities (New Directions for Teaching and Learning, no. 132; pp. 99-111). San Francisco, CA: Jossey-Bass. 
National Task Force on Civic Learning and Democratic Engagement. (2012). A crucible moment: College learning and democracy's future. Washington, DC: Association of American Colleges and Universities.

Piaget, J. (1972). Psychology and epistemology: Towards a theory of knowledge. Harmondsworth: Penguin.

Rowan-Kenyon, H. Soldner, M., \& Inkelas, K. K. (2007). The contributions of livinglearning programs on developing a sense of civic engagement in undergraduate students. NASPA Journal, 44(4), 750-778.

Schlossberg, N. K. (1989). Marginality and mattering: Key issues in building community. In D. C. Roberts (Ed.), Designing campus activities to foster a sense of community (New Directions for Student Services, No. 48; pp. 5-15). San Francisco: Jossey-Bass.

Seidman, I. (2012). Interviewing as qualitative research: A guide for researchers in education and the social sciences. New York: Teachers College Press.

Spiezio, K. E., Baker, K., Q., \& Boland, K. (2006). General education and civic engagement: An empirical analysis of pedagogical possibilities. The Journal of General Education, 54(4), 273-292.

Taylor, K., Moore, W. S., MacGregor, J., \& Lindblad, J. (2003). What we know now about learning community research and assessment. National Learning Communities Project Monograph Series. Olympia, WA: Washington Center for Improving the Quality of Undergraduate Education, The Evergreen State College.

Watterson, N., Rademacher, N., \& Mace D. (2012). Foregrounding relationships: Using deliberative dialogue and engaged justice in a living and learning community. Journal of College and Character, 13(2), 1-8.

Wawrzynski, M. R., \& Jessup-Anger, J. E. (2010). From expectations to experiences: Using a structural typology to understand first-year student outcomes in academically based living-learning environments. Journal of College Student Development, 51, 201-217.

Wawrzynski, M. R., Jessup-Anger, J. E., Helman, C., Stolz, K., \& Beaulieu, J. (2009). Exploring students' perceptions of academically based living-learning communities. College Student Affairs Journal, 28, 138-158.

Yin, R. (1984). Case study research: Design and methods. Beverly Hills, CA: Sage Publishing. 